\title{
FDI, Employment, and Economic Growth of Beijing City: Mechanism and Empirical Test
}

\author{
Yunmeng Li, Liyan Liu* \\ School of Economics and Management, Beijing Institute of Petrochemical Technology, Beijing, China \\ Email: *lucyliuliyan@bipt.edu.cn
}

How to cite this paper: Li, Y.M. and Liu, L.Y. (2019) FDI, Employment, and Economic Growth of Beijing City: Mechanism and Empirical Test. Theoretical Economics Letters, 9, 2070-2084. https://doi.org/10.4236/tel.2019.96130

Received: June 24, 2019

Accepted: August 26, 2019

Published: August 29, 2019

Copyright $\odot 2019$ by author(s) and Scientific Research Publishing Inc. This work is licensed under the Creative Commons Attribution International License (CC BY 4.0).

http://creativecommons.org/licenses/by/4.0/

\section{cc) (i) Open Access}

\begin{abstract}
This study was set out to investigate the linkages between employment, FDI and economic growth of Beijing city, and the mechanism of FDI's impact on employment and the city's economic growth. Channels of FDI's spillover mechanism on employment and economic growth are identified. And based on sixteen district-level data of Beijing city from 2006 to 2017, we use panel data model to test the linkages between FDI, employment and city's economic growth. Findings show that for the six inner-city districts with well-developed economy structure and city infrastructure, both FDI and Employment have a positive influence on the economic growth; while for the ten outer-city districts, economic growth seems to be fueled by employment and fixed capital investment.
\end{abstract}

\section{Keywords}

Employment, FDI, Economic Growth, Mechanism

\section{Introduction}

Foreign direct investment (FDI) refers to the foreign capital's direct investment to China's economy, which is according to the existing investment policies of the host country. It not only promotes the development of the host country's economy and improves the living standards of the people, but also has an important impact on the employment of the host country.

As an important measure of promoting the development of the domestic economy, FDI plays an increasingly important role in the world economy. Since the reform and opening, China has continuously expanded the scale and improved the level of foreign capital utilization. In 2003, China introduced more FDI than that of the United States, becoming the world's largest host country for FDI.

${ }^{*}$ Corresponding author. 
However, because of the differences in regional openness, investment policies and economic development levels, the regional distribution of FDI shows unbalanced characteristics. FDI has different impacts on economic development, employment and efficiency. However, due to the great differences in human resource endowment and infrastructure conditions in different regions, the impact of FDI on economic growth and employment presents a multifaceted feature.

As China's first metropolis of service industry opening to the outside world and China's foreign exchange center, Beijing attracted 24,329.9 million US dollars of foreign investment in 2017, accounting for $18.57 \%$, nearly one fifth of China's foreign investment ${ }^{1}$. At the same time, Beijing is a relatively vast city and large market with 16,412 square kilometers, a population of 21.707 million $^{2}$. In terms of administrative division, Beijing includes 16 districts-six urban districts and ten suburban districts. The economic development mode, industrial structure, industrial development, natural endowment, infrastructure and other conditions of the districts and counties are quite different, and the degree of opening to the outside world is relatively high. As a super-large open city in developing counties, FDI has become one of the important driving forces of Beijing's economic development. Beijing has developed relatively smoothly in terms of employment and foreign direct investment. Therefore, it has certain realistic significance to explore Beijing's FDI, employment and economic growth for other large cities in developing counties to utilize FDI and develop their own economy.

In this study, we try to investigate the impact mechanism of FDI on the economic growth and employment of the host country under the framework of an open economy context and using data of sixteen districts in Beijing as samples for empirical tests. The rest of the paper is organized as follows: II. Literature review; III. Theoretical Framework: Mechanism, in which part we established a two-country and two-sector economy model in world economy and made a theoretical analysis on the channels of FDI's spillover mechanism; IV. Empirical Test: in this part we use dataset of sixteen districts in Beijing to empirically test the topic; V. Conclusion.

\section{Literature Review}

Research on the impact of FDI on host economies generally uses different samples and empirical test methods. Because of different economic development and resource endowments of host countries, the conclusions are also quite different. The research on FDI and employment or economic growth mainly discusses the influence of FDI on the national economic development, employment creation, employment substitution effect and wage level of the host country.

Many studies focused on the issue of the impact of foreign direct investment on employment. $\mathrm{Xu}$, Yuan and $\mathrm{Li}[1]$ used the panel data of Chinese manufacturing enterprises and GMM method to explore the impact of FDI on China's domestic enterprise, and found that FDI have the positive spillover effects on ${ }^{1}$ Data calculated from the original data of Beijing Statistical Yearbook (2018).

${ }^{2}$ Data derived from Beijing Statistical bulletin (2019). 
domestic enterprise's wage and employment quality. Aktar and Ozturk [2] believed that FDI will create more jobs for Turkey and proposed that Turkey should increase the qualifications of labor force so as to attract more and better FDI to create new jobs. Jianwei Xu and Qiyou Guo [3] used provincial data of China and GMM method based on panel data from year 1994 to 2013 to study the interactive effects of employment, wage, economic growth, and FDI, and found that FDI in the east of China has more significant effect on economic growth but weaker impact on employment, while FDI in the west part of China has a stronger employment effect but insignificant economic growth effect. Liyan Liu [4] used EG co-integration method, Granger causality test and ECM model to explore the long-run and short-term employment effect of FDI in China from year 1985 to 2008, and found that growth of FDI in the long run would promote employment in secondary and service industry, while in the short term FDI has limited and even negative impetus on employment, with the latter indirectly increasing the former. Figini [5] used over one hundred countries data from year 1980 to 2002 to study the impact of FDI on employment and wage and found that FDI's impact on employment and wage is subject to the development stage of the host country.

FDI is not only a major influencing factor for employment in the host country, but also impacts the growth of the host country's national economy. Qian Dai and Zhaoxia Bie [6] established endogenous economic growth model and found that not all FDI will promote the economic growth and technology development in developing countries. Only for those developing countries with comparatively high speed of accumulation of human capital, FDI will promote the host county's economic growth and technology development. Zhang [7] used data from East Asia and Latin America countries to investigate the relation between FDI and economic growth in developing countries, and found that the impact of FDI on economic growth is subject to host countries own development status, and for those countries with stable economic development, free trade system, high level of education and human resources investment, FDI will have a stronger positive economic growth effect. While Liyan Liu [8] used VAR and ECM model under a comprehensive framework with from mainland China, and claimed that FDI tends to decrease economic growth in the long run, and economic development in China seems to be fueled by domestic capital accumulation and employment growth; FDI inflows do crowd out domestic capitals, and reduce employment growth. Herzer Dierk, Klasen Stephan and Nowak-Lehmann Felicitas [9] tested the growth hypothesis of cointegration test on the data of 28 developing countries, the general view that FDI has a positive impact on the economic growth of developing countries is questioned. The results show that FDI has neither long-term nor short-term effects on economic growth in most countries. In addition, there is no definite link between FDI and per capita income level, education level and financial market openness in developing counties. Some scholars hold different opinions that the impact of foreign direct investment on the economic growth of 
the host country depends on the characteristics of the host country itself. Moudatsou Argiro and Kyrkilis Dimitrios [10] Using panel data from two different economic organizations of the European Union (EU) and ASEAN (Association of Southeast Asian Nations) from 1970 to 2003, this paper studies the causal relationship between foreign direct investment and economic growth. The empirical results of heterogeneous panel analysis show that for EU counties, the research results support the ASEAN panel's assumption that the host country's economic growth attracts FDI, and there is a causal relationship between GDP per capita and FDI. However, in Singapore, Philippines and other suburbs, foreign direct investment is driven by the host country's GDP growth.

The impact of foreign direct investment on the host country is multiple and interactive, and current studies are mainly based on Douglas production function. This paper is dedicated to establishing a two-sector model of the two countries under an open economy and exploring the impact mechanism of FDI on the economic growth and employment of the host country. The data of 16 districts and counties in Beijing are taken as samples for empirical tests.

\section{Theoretical Framework: Mechanism}

In order to study the interactive effects of FDI on economic growth, employment and wage level, and detect the mode of economic growth in super cities with rapid growth of services, we established an open economy model with the following assumptions:

1) Open economy: the economy is an open economy in the world market;

2) Two-sector economy: consists of two sectors, households and firms;

3) Two-country economy: consists of two country domestic and foreign country;

4) Total investment of the country comes from domestic capital (D) and international capital (FDI).

\section{1) Households Behavior}

Under the budget constraint, households will try to optimize their utilities by choose the most appropriate consumption and employment level defined by the time point on the budget constraint line.

The utility function of households can be defined as:

$$
E\left(U_{t}\right)=\sum_{t=0}^{\infty} \beta^{t}\left(\frac{1}{1-\sigma} c_{t}^{1-\sigma}-\frac{1}{1+\omega} L_{t}^{1+\omega}\right)
$$

$$
\text { St. } P_{t} C_{t}=w_{t} L_{t}+D_{D, t}
$$

$C_{t}$ refers to the consumption level of households, and $D_{D, t}$ refers to the firms' residual profits gained by the domestic households.

\section{2) Firms Behavior}

Firms use capital and labor factors for their production, and their production function can be defined as:

$$
Y_{t}=A_{t}\left(K_{t}\right)^{\alpha}\left(L_{t}\right)^{1-\alpha}
$$


$A_{t}$ refers to the technology level of time period $t, L_{t}$ represents for the labor input of time period $t$, and $K_{t}$ is capital level of time period $t$, including domestic fixed investment and FDI.

And assume that fixed investment and FDI have the same depreciation rate $\delta$, then the dynamic functions for domestic and foreign capital (FDI) would be

$$
\begin{aligned}
K_{D . t+1} & =(1-\delta) K_{D . t}+I_{D . t} \\
K_{F, t+1} & =(1-\delta) K_{F . t}+I_{F . t}
\end{aligned}
$$

$K_{D . t}$ is domestic investment accumulation in fixed assets in period $t, K_{F . t}$ is the accumulation of FDI in fixed assets in period $t ; I_{D . t}, I_{F . t}$ are domestic investment and FDI in period $t$ respectively; $\delta$ represents for depreciation rate.

Domestic investment and FDI shown in the $t$ period; $\delta$ represents the capital depreciation rate.

Assume that each period of domestic investment and FDI meet the following equation:

$$
I_{F . t}=\gamma I_{D . t}
$$

Given zero initial capital stock, domestic investment accumulation and FDI accumulation would be equal.

$$
K_{F . t}=\gamma K_{D . t}
$$

Meanwhile, assume that the remaining profits after firms' paying for wages and investments are allocated based on the share of capital held by the households.

Firms' profits would be:

$$
\Pi_{t}=P_{t} Y_{t}-w_{t} L_{t}-\left(P_{t} I_{d . t}+P_{t} I_{F . t}\right)-D_{t}
$$

$P_{t}, w_{t}, L_{t}$ refers to the price index, wage level and employment level of period

$D_{t}$ is the total dividend, including dividends distributed by domestic households, $D_{D, t}$, and by foreign residents, $D_{F . t}$.

$$
D_{t}=D_{D . t}+D_{F . t}
$$

And the relation between domestic dividends and foreign dividends meets the following equation:

$$
D_{F . t}=\gamma D_{D . t} \text {, }
$$

3) Equilibrium Analysis. Assume that $A_{t}=1$, and $P_{t}=1$, then we have the following equations for the economy:

Consumption,

$$
C=\frac{(1-\beta+\delta \beta-\delta \alpha \beta)^{\frac{\omega}{v+\omega}}(\alpha \beta)^{\frac{\alpha+\omega v}{v+\omega-\alpha v-\alpha \omega}}(1-\alpha)^{\frac{1}{\alpha+\omega}}}{(1-\beta+\delta \beta)^{\frac{\omega+\alpha}{v+\omega-\alpha v-\alpha \omega}}}
$$

Yield of firms,

$$
Y=\frac{1-\beta+\delta \beta}{1-\beta+\delta \beta-\delta \alpha \beta} C
$$


For the capital,

$$
\begin{aligned}
K_{D}+K_{F} & =\frac{\alpha \beta}{1-\beta+\alpha \beta} Y \\
I_{D}+I_{F} & =\delta\left(K_{D}+K_{F}\right)
\end{aligned}
$$

For the domestic households' dividends presented by $K$,

$$
D_{D}=\frac{1}{1+\gamma} \frac{1-\beta}{\beta}\left(K_{D}+K_{F}\right)
$$

For the wage represented by $\alpha, \beta$ and $\delta$,

$$
w=(1-\alpha)\left(\frac{\alpha \beta}{1-\beta+\delta \beta}\right)^{\frac{\alpha}{1-\alpha}}
$$

For the yield represented by $L$

$$
\left(\frac{\alpha \beta}{1-\beta+\delta \beta}\right)^{\frac{\alpha}{1-\alpha}} L=Y
$$

For the domestic households' dividends presented by $C$,

$$
D_{D}=\frac{1}{1+\gamma} \frac{\alpha(1-\beta)}{1-\beta+\delta \beta-\delta \alpha \beta} C
$$

For the capital,

$$
\begin{gathered}
K_{F}=\gamma K_{D} \\
I_{F}=\gamma I_{D}
\end{gathered}
$$

4) Dynamic Analysis. To investigate the impact of FDI on the yield, employment, we made logarithm transformation for the equation and get the following form of FDI:

$$
\begin{aligned}
& \frac{1}{(\delta-1)} \hat{K}_{F . t+1}+\hat{K}_{F . t} \\
& =\left[\frac{\eta(\delta-1)+\alpha}{\alpha \eta(\delta-1)} \hat{Y}_{t}-\frac{1}{\eta(\delta-1)}(1-\eta) \hat{Y}_{t+1}\right] \\
& +\left\{\frac{1}{\eta(\delta-1)}(B+1) \hat{L}_{t+1}-\left[\frac{\alpha+(1-\alpha) \eta(\delta-1)}{\eta \alpha(\delta-1)}-\frac{B(1+\gamma)}{\eta \gamma(\delta-1)}\right] \hat{L}_{t}\right\} \\
& +\frac{1}{\eta(\delta-1)} A
\end{aligned}
$$

The relation between wage and employment can be defined as:

$$
\hat{w}_{t}=B \hat{L}_{t}
$$

And $B$ can be presented as

$$
B=\frac{\left(2 I_{D}+0.5 \omega I_{D}+w L\right)(1+\gamma)+(2 C+0.5 \omega C)(\sigma-\gamma+\gamma \sigma)-(1+\alpha-0.5 \omega) Y}{1.5 I_{D}(1+\gamma)+1.5 C(\sigma-\gamma+\gamma \sigma)-(0.5+\alpha) Y-(1+\gamma) w L}
$$

From Equation (21), we can see that the change of FDI is strongly connected with the change of yields (GDP), employment and technology level. Therefore, 
the capital accumulated by the inflow of FDI has an interactive effect with the yields (GDP), employment in an open economy, and the inflow of FDI will impact the economic growth and employment level in an economy context.

\section{Empirical Test}

\subsection{Econometric Model and Data Description}

According to the above theoretical model, foreign direct investment, employment and economic growth have interactive effects, while domestic investment is also a factor of economic growth. The following econometric models are set in this paper:

$$
\ln G D P_{i t}=\alpha+\beta_{1} \ln F D I_{i t}+\beta_{2} \ln E M P_{i t}+\beta_{4} \ln F I X_{i t}+\epsilon_{i t}
$$

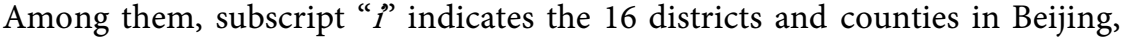
and " $"$ " indicates the year. $G D P_{i t}$ is the output value of all districts and counties in Beijing during the $t$ period, i.e. economic growth; $F D I_{i t}$ indicates the actual amount of foreign capital used by each district in Beijing during the $t$ period; $E M P_{i t}$ indicates the number of labor force input in each district in Beijing during the $t$ period, which is the number of people employed in each district at the end of the year. FIX ${ }_{i t}$ is the fixed capital investment of Beijing's districts in the $t$ period, expressed by the annual fixed asset investment of 16 districts in Beijing.

Beijing has 16 districts, namely Dongcheng District, Xicheng District, Chaoyang District, Fengtai District, Shijingshan District, Haidian District, Mentougou District, Fangshan District, Tongzhou District, Shunyi District, Changping District, Daxing District, Huairou District, Pinggu District, Miyun District and Yanqing District. From 2006 to 2009, Chongwen District and Xuanwu District in Beijing have not been included into Dongcheng District and Xicheng District respectively. In 2010, Chongwen District was merged into Dongcheng District and Xuanwu District was merged into Xicheng District. To maintain statistical consistency, Chongwen District data was added to Dongcheng District data from 2006 to 2009, and Xicheng District data included Xuanwu District data.

We selected the data of Beijing from 2006 to 2017, and data for the economic growth we directly use the GDP of 16 districts in Beijing. The GDP of each district, the actual utilization of FDI in each district and the annual fixed asset investment of each district are all in units of RMB 10,000.00 Yuan, which is converted and eliminated inflation according to the current year's exchange rate and CPI data of the National Bureau of Statistics. All data are from Beijing's Statistical Yearbook and China Statistical Yearbook. We used Stata 15 to conduct the econometric analysis.

After the inflation removal, exchange rate conversion and logarithmic processing according to Equation (24), the data shows the following characteristics. From the point of view of mean value, standard deviation, maximum value and minimum value, the overall standard deviation of the data is small and there is no abnormal value (Table 1). The data is balanced panel data. 
Table 1. Sum of data statistical characteristics.

\begin{tabular}{ccccccc}
\hline Variable & & Mean & Std. Dev. & Min & Max & Observations \\
\hline lngdp & Overall & 15.21849 & 1.340272 & 12.28282 & 17.8844 & $\mathrm{~N}=192$ \\
& Between & & 0.6200017 & 14.00712 & 14.00712 & $\mathrm{n}=12$ \\
& Within & & 1.200881 & 13.38068 & 17.54987 & $\mathrm{~T}=16$ \\
$\operatorname{lnfdi}$ & Overall & 11.32035 & 1.850178 & 6.38851 & 15.8588 & $\mathrm{~N}=192$ \\
& Between & & 0.3545875 & 10.80474 & 12.10773 & $\mathrm{n}=12$ \\
& Within & & 1.818599 & 6.319543 & 15.83315 & $\mathrm{~T}=16$ \\
$\ln$ lnemp & Overall & 12.44816 & 1.026051 & 10.72234 & 14.36897 & $\mathrm{~N}=192$ \\
& Between & & 0.1240273 & 12.20337 & 12.57642 & $\mathrm{n}=12$ \\
& Within & & 1.01912 & 10.66683 & 14.28869 & $\mathrm{~T}=16$ \\
$\operatorname{lnfix}$ & Overall & 14.71482 & 0.9162975 & 12.31626 & 16.4068 & $\mathrm{~N}=192$ \\
& Between & & 0.3905798 & 14.02825 & 15.18901 & $\mathrm{n}=12$ \\
& Within & & 0.8360718 & 13.00282 & 16.75393 & $\mathrm{~T}=16$ \\
\hline
\end{tabular}

\subsection{Test Results}

\section{Pooled Regression}

As a reference, we first carry out pooled regression, which assumes that all sixteen districts have the same regression equation and that there are no individual specific effects, that is, no constant terms. The pooled regression equation for the four cities is uniformly set as follows:

$$
y_{i t}=\alpha+x^{\prime} \beta+z_{i}^{\prime} \delta+\epsilon_{i t}
$$

Three forms of pooled regression, as Cluster-robust standard error pooled regression, heteroscedasticity robust standard error pooled regression and common standard error pooled regression were performed respectively.

As the natural endowments and development patterns of the six inner city districts and ten outer city districts are quite different, we divided the 16 districts into two groups-the six inner-city districts and the ten outer-city districts. We carry out full sample regression based on all sixteen districts, and two sub-sample regression based on the six inner-city districts and ten outer-city districts respectively.

From the results in Table 2, we can see that the three forms of pooled regression for all samples in 16 districts in Beijing are quite different. The coefficient values of the three results are the same, but the standard error of cluster-robust standard error pooled regression is much higher than that of robust standard error and standard error pooled regression. The pooled regression results of robust standard error and common standard error are relatively close. Employment and fixed asset investment are significant at $1 \%$ statistical level, while FDI is significant at $5 \%$ statistical level. The cluster-robust standard error regression results are quite different from the other two, FDI is not significant, employment and fixed asset investment have significant effects. 
There are three forms of pooled regression for the six inner-city districts as shown in Table 3. The coefficient values of variables in the three regression results are the same. All variables in Cluster-robust standard error Pooled Regression are not significant. In the Robust standard error and Standard error pooled regressions, only fixed asset investment is not significant, FDI and employment are significant.

According to the pooled regression results in the outer-city districts as shown in Table 4, FDI and employment is not significant in cluster-robust standard error pooled regression, fixed asset investment is significant. In the robust standard error and standard error pooled regressions, FDI is not significant, while fixed asset investment and employment are significant.

\section{F-Test}

Different forms of the pooled regression results are quite different. At the same time, it is assumed that the 16 districts and suburb in Beijing have the same regression equation with no individual difference in the pooled regression. Each district has its own characteristics and economic development mode and may have its own characteristics, that is heterogeneity. Therefore, we need to investigate confirm the effectiveness of pooled regression through F-test.

Table 2. Comparison of three pooled regression of full sample.

\begin{tabular}{|c|c|c|c|c|c|c|c|c|c|}
\hline \multirow{2}{*}{$\operatorname{lngdp}$} & \multicolumn{3}{|c|}{ Cluster-Robust standard error } & \multicolumn{3}{|c|}{ Robust standard error } & \multicolumn{3}{|c|}{ Standard error } \\
\hline & Coef. & Std. Err. & $P>|t|$ & Coef. & Std. Err. & $P>|t|$ & Coef. & Std. Err. & $P>|t|$ \\
\hline $\operatorname{lnemp}$ & 0.8087159 & 0.1492335 & 0.000 & 0.8087159 & 0.0737671 & 0.000 & 0.8087159 & 0.0718668 & 0.000 \\
\hline $\operatorname{lnfix}$ & 0.4039206 & 0.1324439 & 0.008 & 0.4039206 & 0.0606188 & 0.000 & 0.4039206 & 0.0591712 & 0.000 \\
\hline _cons & -1.615436 & .906603 & 0.095 & -1.615436 & 0.5861177 & 0.006 & -1.615436 & 0.6543677 & 0.014 \\
\hline
\end{tabular}

Table 3. Comparison of three pooled regression of inner-city districts.

\begin{tabular}{|c|c|c|c|c|c|c|c|c|c|}
\hline \multirow{2}{*}{$\operatorname{lngdp}$} & \multicolumn{3}{|c|}{ Cluster-Robust standard error } & \multicolumn{3}{|c|}{ Robust standard error } & \multicolumn{3}{|c|}{ Standard error } \\
\hline & Coef. & Std. Err. & $P>|t|$ & Coef. & Std. Err. & $P>|t|$ & Coef. & Std. Err. & $P>|t|$ \\
\hline $\operatorname{lnemp}$ & 0.9123061 & 0.2602459 & 0.017 & 0.9123061 & 0.1225783 & 0.000 & 0.9123061 & 0.1230398 & 0.000 \\
\hline $\operatorname{lnfix}$ & -0.0571393 & 0.1693772 & 0.750 & -0.0571393 & 0.0864804 & 0.511 & -0.0571393 & 0.0856695 & 0.507 \\
\hline _cons & 1.836735 & 1.028626 & 0.134 & 1.836735 & 0.9950739 & 0.069 & 1.836735 & 1.102191 & 0.100 \\
\hline
\end{tabular}

Table 4. Comparison of three pooled regression of outer-city districts.

\begin{tabular}{|c|c|c|c|c|c|c|c|c|c|}
\hline \multirow{2}{*}{ lngdp } & \multicolumn{3}{|c|}{ Cluster-Robust standard error } & \multicolumn{3}{|c|}{ Robust standard error } & \multicolumn{3}{|c|}{ Standard error } \\
\hline & Coef. & Std. Err. & $P>|t|$ & Coef. & Std. Err. & $P>|t|$ & Coef. & Std. Err. & $P>|t|$ \\
\hline lnemp & 0.2873142 & 0.2380226 & 0.258 & 0.2873142 & 0.1068559 & 0.008 & 0.2873142 & 0.1077709 & 0.009 \\
\hline $\operatorname{lnfix}$ & 0.7742482 & 0.0877795 & 0.000 & 0.7742482 & 0.0588852 & 0.000 & 0.7742482 & 0.0693742 & 0.000 \\
\hline _cons & -0.4509164 & 1.817321 & 0.810 & -0.4509164 & 0.7785967 & 0.564 & -0.4509164 & 0.7875797 & 0.568 \\
\hline
\end{tabular}


For the F test (Table 5) of the full sample of Beijing, the sub-sample of six inner-city and ten outer-city districts, the $\mathrm{P}$ values of the three samples are 0.0000 , which is strongly rejecting the original hypothesis that the individual difference is 0 , so there are individual differences, and the above pooled regression results are not valid.

However, since the $\mathrm{F}$ test here does not use cluster robust standard error but standard error, the error of which is only about half of the cluster standard error. Therefore, the simple $\mathrm{F}$ test is not effective enough. We also need to conduct LSDV (LEAST SQUARE DUMMY VARIABLE TEST) test to further determine the validity and scientific of the $\mathrm{F}$ test results.

From Table 6 we can see that LSDV test of full sample shows that, except district Table 5. F-test for full sample and sub-samples.

\begin{tabular}{|c|c|c|c|}
\hline & $\begin{array}{l}\text { Full Sample (16) } \\
\text { All districts }\end{array}$ & $\begin{array}{c}\text { Subsample } \\
\text { Inner-city Districts (6) }\end{array}$ & $\begin{array}{c}\text { Subsample } \\
\text { Outer-city Districts (10) }\end{array}$ \\
\hline & Coef. & Coef. & Coef. \\
\hline sigma_u & 0.4578979 & 0.35267249 & 0.44843529 \\
\hline sigma_e & 0.32020643 & 0.19144333 & 0.28210487 \\
\hline \multirow[t]{3}{*}{ rho } & 0.6715846 & 0.77239703 & 0.71646036 \\
\hline & $\mathrm{F}$ test that all $\mathrm{u} \_\mathrm{i}=0: \mathrm{F}(11,177)$ & $\mathrm{F}$ test that all $\mathrm{u} \_\mathrm{i}=0: \mathrm{F}(11,57)$ & $\mathrm{F}$ test that all $\mathrm{u} \_\mathrm{i}=0: \mathrm{F}(11,105)$ \\
\hline & $=25.30$ Prob $>F=0.0000$ & $=19.09$ Prob $>F=0.0000$ & $=15.76$ Prob $>F=0.0000$ \\
\hline
\end{tabular}

Note: rho coefficient value: fraction of variance due to $u \_i$.

Table 6. Least square dummy variable test for full sample.

\begin{tabular}{|c|c|c|c|c|c|c|}
\hline \multirow{2}{*}{ Districs } & \multicolumn{2}{|c|}{ Full Sample (16) } & \multicolumn{2}{|c|}{ Inner-City Districts (6) } & \multicolumn{2}{|c|}{ Outer-City Districts (10) } \\
\hline & Coef. & $\mathrm{P}>|\mathrm{t}|$ & Coef. & $P>|t|$ & Coef. & $P>|t|$ \\
\hline 2 & -0.3857458 & 0.041 & -0.6109722 & 0.036 & & \\
\hline 3 & -1.780356 & 0.000 & -1.991455 & 0.001 & & \\
\hline 4 & -1.246551 & 0.000 & -0.7526192 & 0.034 & & \\
\hline 5 & 1.080898 & 0.038 & 1.921152 & 0.017 & & \\
\hline 6 & -1.638398 & 0.000 & -1.976059 & 0.002 & & \\
\hline 7 & 2.186978 & 0.036 & & & & \\
\hline 8 & 0.91868 & 0.150 & & & -0.9670104 & 0.062 \\
\hline 9 & 0.1942979 & 0.681 & & & -1.503784 & 0.036 \\
\hline 10 & -0.0943849 & 0.652 & & & -1.519344 & 0.128 \\
\hline 11 & 0.1425291 & 0.724 & & & -1.500832 & 0.058 \\
\hline 12 & -1.008128 & 0.000 & & & -2.466602 & 0.024 \\
\hline 13 & 2.117982 & 0.013 & & & 0.2028475 & 0.366 \\
\hline 14 & 1.694446 & 0.026 & & & -0.1738456 & 0.558 \\
\hline 15 & 1.78363 & 0.025 & & & -0.1529691 & 0.570 \\
\hline 16 & 2.489651 & 0.012 & & & 0.4380287 & 0.001 \\
\hline _cons & -19.93932 & 0.001 & -24.58106 & 0.004 & -14.96272 & 0.016 \\
\hline
\end{tabular}


dummy 9, 10, 11, all other district dummies are significant at $1 \%$ or $5 \%$ level; the $\mathrm{P}$-value of inner-city LSDV test are all significant at $1 \%$ or $5 \%$ level; the P-value of outer-city LSDV test are significant at $1 \%$ or $5 \%$ level except district dummy $13,14,15$. Therefore, the null hypothesis that all dummies are 0 value is rejected. Hence there are individual-specific effects, and each district has its time invariant heterogeneity. Pooled regression results are not effective, and we should use individual-specific effect model to investigate the interactions of FDI, employment and economic growth in 16 districts of Beijing city.

Fixed Effect Model and Random Effect Model

Since there are individual-specific effects, we first use Fixed Effects Model $(\mathrm{FE})^{3}$ and Random Effect Model (RE) respectively to investigate the impact of FDI and employment on economic growth of Beijing.

From results of FE model (Table 7) and RE model (Table 8) we can see that significance of variables in full sample regression are quite similar, FDI, employment and fixed investment are all significant in FE and RE; and in inner-city

Table 7. Fixed effect model regression.

\begin{tabular}{|c|c|c|c|c|c|c|c|c|c|}
\hline \multirow{2}{*}{$\operatorname{lngdp}$} & \multicolumn{3}{|c|}{ Full Sample (16) } & \multicolumn{3}{|c|}{ Inner-City Districts (6) } & \multicolumn{3}{|c|}{ Outer-City Districts (10) } \\
\hline & Coef. & Std. Err. & $P>|t|$ & Coef. & Std. Err. & $P>|t|$ & Coef. & Std. Err. & $P>|t|$ \\
\hline $\operatorname{lnfdi}$ & 0.0517787 & 0.0274592 & 0.086 & 0.2080206 & 0.0393413 & 0.000 & 0.0212572 & 0.0196129 & 0.302 \\
\hline lnemp & 1.010735 & 0.0405765 & 0.000 & 0.9905337 & 0.0642473 & 0.000 & 0.6408056 & 0.0460621 & 0.000 \\
\hline $\operatorname{lnfix}$ & 0.0768878 & 0.0308793 & 0.030 & -0.1530611 & 0.0380272 & 0.002 & 0.3343469 & 0.0347329 & 0.000 \\
\hline _cons & 0.9191556 & 0.5544345 & 0.126 & 2.771295 & 0.5395466 & 0.000 & 1.863605 & 0.3106699 & 0.000 \\
\hline sigma_u & 0.4578979 & & & 0.35267249 & & & 0.44843529 & & \\
\hline sigma_e & 0.32020643 & & & 0.19144333 & & & 0.28210487 & & \\
\hline rho & 0.6715846 & & & 0.77239703 & & & 0.71646036 & & \\
\hline
\end{tabular}

Note: rho value: fraction of variance due to $u \_i$.

Table 8. Random effect model regression.

\begin{tabular}{|c|c|c|c|c|c|c|c|c|c|}
\hline \multirow{2}{*}{$\operatorname{lngdp}$} & \multicolumn{3}{|c|}{ Full Sample (16) } & \multicolumn{3}{|c|}{ Inner-City Districts (6) } & \multicolumn{3}{|c|}{ Outer-City Districts (10) } \\
\hline & Coef. & Std. Err. & $P>|t|$ & Coef. & Std. Err. & $P>|t|$ & Coef. & Std. Err. & $P>|t|$ \\
\hline $\operatorname{lnfdi}$ & 0.0614819 & 0.033221 & 0.064 & 0.2370243 & 0.0399141 & 0.000 & 0.0270518 & 0.0219909 & 0.219 \\
\hline $\operatorname{lnemp}$ & 0.9186269 & 0.059506 & 0.000 & 0.9357113 & 0.0742261 & 0.000 & 0.4986876 & 0.0793685 & 0.000 \\
\hline $\operatorname{lnfix}$ & 0.2249329 & 0.0720881 & 0.002 & -0.0882628 & 0.0534681 & 0.099 & 0.5090716 & 0.0717361 & 0.000 \\
\hline _cons & -0.2225677 & 0.9405615 & 0.813 & 2.158802 & 0.6663761 & 0.001 & 0.9630558 & 0.425058 & 0.023 \\
\hline sigma_u & 0.10211716 & & & 0.05737731 & & & 0.14995055 & & \\
\hline sigma_e & 0.32020643 & & & 0.19144333 & & & 0.28210487 & & \\
\hline rho & 0.09231505 & & & 0.08242194 & & & 0.22029524 & & \\
\hline
\end{tabular}

Note: rho value:fraction of variance due to u_i.

${ }^{3}$ Even in fixed effects model, individual-specific effects " $\mu_{i}$ ” is still a random one, but not a fixed constant. 
regression, all variables are significant; and outer-city regression, FDI are not significant in both FE and RE model. Most of the difference lies in the coefficients of variables of the two methods, as we can see from the two tables.

Which result is more effective and reliable? We must take Hausman test to further investigate the validity of the two results.

\section{Further Test: Hausman Test}

In order to further illustrate the validity and scientificity of the estimation results of the above fixed effect model and random effect model, we carry out Hausman Test to further investigate the effectiveness of the regression results of in Table 7 and Table 8.

Test results in Table 9 show that $P$ value equals 0.0000 , which strongly reject the $\mathrm{H}_{0}$, that is the difference in coefficients is systematic, and fixed effects regression is effective. Therefore, fixed effect model regression in Table 7 is reliable and scientific, and our discussion will be based on results of fixed effect regression.

\subsection{Discussion}

According to the fixed effect regression results (Table 7), under the full sample regression, the coefficient of FDI is 0.0518 for the 16 districts and suburbs in Beijing, which has a positive effect on economic growth. For every $1 \%$ increase in FDI, the total economic growth is $0.0518 \%$. FDI is significant at the statistical level of $10 \%$. This positive correlation shows that the inflow of FDI will drive the overall economic development of Beijing. Employment in 16 districts has a significant positive effect on economic growth at the level of $1 \%$. Fixed asset investment has a positive effect on economic growth and is significant at the statistical level of $5 \%$.

The regression results of six inner-city districts are different from those of 16 districts and outer-city districts in Beijing. FDI plays a more significant role in promoting economic growth. Statistically, it is at a significant level of $1 \%$, with a coefficient of 0.208 , which indicates that for every $1 \%$ increase in FDI inflow, the total economic growth is $0.208 \%$. The economic growth effect of employment is also significant, but the coefficient is slightly lower, 0.99 ; it is worth noting that the rate of return on fixed investment is negative, with a coefficient of -0.153 . This result is contrary to common sense. Increasing capital input should normally increase output rather than decrease it. The six inner-city districts of Beijing include districts of Dongcheng, Xicheng, Chaoyang, Fengtai, Shijingshan

Table 9. Hausman test for full and sub-sample.

\begin{tabular}{ccc}
\hline \multirow{2}{*}{ Full sample } & \multicolumn{1}{c}{ Chi } & P \\
\cline { 2 - 3 } & chi2 $(4)=(\mathrm{b}-\mathrm{B})^{\prime}\left[\left(\mathrm{V} \_\mathrm{b}-\mathrm{V} \_\mathrm{B}\right)^{\wedge}(-1)\right](\mathrm{b}-\mathrm{B})=72.04$ & Prob $>$ chi2 $=0.0000$ \\
\hline Inner City & chi2 $(4)=(\mathrm{b}-\mathrm{B})^{\prime}\left[\left(\mathrm{V} \_\mathrm{b}-\mathrm{V} \_\mathrm{B}\right)^{\wedge}(-1)\right](\mathrm{b}-\mathrm{B})=45.50$ & Prob $>$ chi2 $=0.0000$ \\
Outer City & chi2 $(4)=(\mathrm{b}-\mathrm{B})^{\prime}\left[\left(\mathrm{V} \_\mathrm{b}-\mathrm{V} \_\mathrm{B}\right)^{\wedge}(-1)\right](\mathrm{b}-\mathrm{B})=37.43$ & Prob $>$ chi2 $=0.0000$ \\
\hline
\end{tabular}

Note: 1. (b): FE; (B): RE; (b-B): difference; $b=$ consistent under Ho and Ha; obtained from xtreg; $B=$ inconsistent under Ha, efficient under Ho; obtained from xtreg; 2 . Ho: difference in coefficients not systematic; 3. V_b-V_B is not positive definite. 
and Haidian. The economic development of the six districts is rapid and the urban infrastructure construction is perfect. Economic theory shows that when capital is invested to a certain extent, marginal returns will decline. The coefficient of fixed capital investment here is negative, indicating that the fixed investment in the six districts of Beijing has reached saturation. The newly added fixed investment cannot play a role in stimulating economic growth, but also form obstacles to a certain extent.

The regression results of the ten outer-city districts show that FDI has no significant effect on the economic growth of the outer suburbs in Beijing. The economic growth of the outer suburbs mainly depends on the pull of employment and fixed capital investment. The pull of employment is almost twice than that of fixed asset investment, thus showing the core role of employment in the economic growth of the outer suburbs. Compared with the six inner-city districts, the outer-city districts in Beijing have relatively low output value, relatively slow development of service industry, especially high-end service industry, relatively small inflow of foreign capital, especially into knowledge and technology-intensive high-end service industries such as information and software, new service fields, and relatively slow infrastructure construction. For example, Daxing District is dominated by agriculture, while Huairou and Mentougou districts have more natural landscapes. Therefore, FDI has no obvious effect on the economic growth in the outer suburbs, and employment has become the main driving force for economic growth. At the same time, compared with the six districts of the city, the fixed capital investment in the outer suburbs plays a more significant role in promoting economic growth, with a coefficient of 0.334 with greater pulling effect.

\section{Conclusions}

The author analyzed the theoretical mechanism of the interaction among FDI, employment and economic growth by constructing a two-sector and two-country model of an open economy. Based on the panel data of 16 districts and suburb in Beijing from 2006 to 2017, the author empirically tested the effect of foreign direct investment (FDI), employment and economic growth in megacities by constructing a fixed effect panel data model of open economy.

The results show that FDI, employment and economic growth have an interactive effect under the theoretical framework of the two-sector and two-country model. The changes of FDI will directly affect economic growth and employment. According to the full-sample regression empirical test of 16 districts in Beijing, the inflow of FDI will promote the economic growth of the districts and suburbs in Beijing. At the same time, employment and fixed asset investment are also the driving forces of the economic growth of the districts in Beijing. According to sub-sample regressions, the regression results of the six inner-city districts in Beijing show that FDI has a more significant effect on the economic growth of the six districts, and employment is also the core driving force for economic 
growth. However, the fixed asset investment in the six districts has reached the saturation stage, and the increase of fixed asset investment has a certain inhibitory effect on economic growth. The results of the regression of the samples from the outer suburbs are quite different from those of the six districts of the city. The investment in fixed assets in the outer suburbs still plays a significant positive role in economic growth, and the promotion of employment is still significant. However, the effect of FDI on the economic growth in the outer suburbs is not significant. On one hand, it is related to the total amount and the level of FDI inflow in the ten outer suburbs of Beijing, on the other hand, industry guidance of FDI in the outer suburbs of Beijing needs to be strengthened.

Beijing's economic development has entered a service economy mode, featured by further optimization of industrial structure and high-speed and high-end development of service industry. Beijing's service industry has been fully opened and FDI inflow has entered a completely new stage of development. In promoting Beijing's economic innovation and development, we should pay attention to the following aspects: First, we should rationally select sectors FDI inflowed in, and encourage the introduction of those FDI with advanced service industry management experience and new business mode into high-end service sectors and emerging industries, and further enhance the knowledge spillover effect of foreign investment. As for the introduction of FDI in the outer suburbs, FDI should be guided into areas such as agriculture, logistics or catering accommodation, which are the key development areas of the districts to further realize and expand the positive spillover effect of FDI. The second is to focus on job creation and the training of high-end talents. High-end innovative talents can be trained through various scientific research and scientific and technological cooperation methods, and high-end talents can also be introduced through various ways. Third, to improve the rate of return on investment in fixed assets, we should reasonably limit and guide the investment in fixed assets in the six inner-city districts. We should make more rigorous planning, avoid duplication of investment and invest capital in areas with higher marginal rate of return. For the fixed asset investment in the outer suburbs, the investment intensity should be further increased, and at the same time reasonable planning should be carried out to further improve the return rate of fixed asset investment in the ten outer-city districts. The fourth is to further expand the opening-up. On the basis of the full opening-up of Beijing's service industry, according to the industry, industry advantages and development situation of each district and county, reasonably plan the development of the industry, select FDI inflow sectors, make full use of the capital supplement effect and spillover effect of FDI, and promote the innovation and development through further opening up.

\section{Founding}

Supporting projects: 1) The Coupling Mechanism between FDI and Employment Structure in Beijing, Beijing Municipal Education Commission Project 
(SM201510017001); 2) The Optimization of Beijing's Industrial Structure Based on SFDI, Beijing Social Science Foundation Project (13JGC072); 3) The Optimization of Beijing's Industrial Structure Based on FDI in Services, Beijing URT Project (2019J00140); 4) Support Project of High-Level Teachers in Beijing Municipal Universities in the Period of $13^{\text {th }}$ Five-Year Plan.

\section{Conflicts of Interest}

The authors declare no conflicts of interest regarding the publication of this paper.

\section{References}

[1] Xu, L.H., Peng, Y. and Li, H.Z. (2009) FDI, Labor Market and Wage Spillover Effect. Management World, 9, 53-68.

[2] Aktar, I. and Ozturk, L. (2009) Can Unemployment Be Cured by Economic Growth and Foreign Direct Investment in Turkey? International Research Journal of Finance and Economics, 27, 203-211.

[3] Xu, J.W. and Guo, Q.Y. (2016) The Interactive Effect of FDI on Economic Growth, Employment and Wage. The Economist, 6, 15-23.

[4] Liu, L.Y. (2012) FDI and Employment by Industry: A Co-integration Study. Modern Economy, 3, 16-22. https://doi.org/10.4236/me.2012.31003

[5] Figini, P. and Gorg, H. (2006) Does Foreign Direct Investment Affect Wage Inequality? An Empirical Investigation. University of Nottingham Research Paper, 29.

[6] Dai, Q. and Bie, Z.X. (2006) FDI, Accumulation of Human Capital and Economic Growth. Economic Research Journal, 4, 15-27.

[7] Zhang, K.H. (2001) Does Foreign Direct Investment Promote Economic Growth? Evidence from East Asia and Latin America. Contemporary Economic Policy, 19, 175-185. https://doi.org/10.1111/j.1465-7287.2001.tb00059.x

[8] Liu, L.Y. (2011) FDI and Economic Development: Evidence from Mainland China. Journal of Service Science and Management, 4, 419-427. https://doi.org/10.4236/jssm.2011.44047

[9] Dierk, H., Stephan, K. and Felicitas, N.-L. (2008) In Search of FDI-led Growth in Developing Suburbs: The Way Forward. Economic Modelling, 25, 793-810. https://doi.org/10.1016/j.econmod.2007.11.005

[10] Argiro, M. and Dimitrios, K. (2001) FDI and Economic Growth: Causality for the EU and ASEAN. Journal of Economic Integration, 26, 554-577. https://doi.org/10.11130/jei.2011.26.3.554 